\title{
Análise retórica do Salmo 15
}

Orientador: Prof. Leonardo Agostini Fernandes

Pesquisadora: Marta Chiara e Silva

Fonte: Departamento de Teologia da PUC-Rio

\section{Introdução}

A presente pesquisa possibilitou a iniciação ao estudo científico na área de teologia bíblica por meio do conhecimento, aprendizado e aplicação das etapas do método da análise retórica ao S1 15. A importância desse estudo revela-se atual e desafiador. Em primeiro lugar, pelo seu objetivo principal que é lançar novas luzes sobre o referido Salmo, valendo-se da análise retórica, para compreender de modo científico, a mensagem subjacente ao texto em questão. Em segundo lugar, pela contribuição que este pode proporcionar para a ampliação do debate acerca das pesquisas que se inserem na linha de pesquisa da exegese bíblica. O presente estudo pretende oferecer, ainda, uma nova chave de leitura para uma compreensão mais aprofundada sobre as condições exigidas na relação do ser humano com Deus, e para com o seu próximo, além de pode contribuir, também, para ampliar o entendimento dessas relações no campo sócio-religioso contemporâneo.

\section{Objetivos}

Fazer a análise retórica do Salmo 15.

Fazer o levantamento bibliográfico, selecionar e analisar o material.

Conhecer e saber aplicar os instrumentos para uma análise retórica. 